\title{
Accelerated Breakdown of Immunoglobulin G (IgG) in Myotonic Dystrophy: A Hereditary Error of Immunoglobulin Catabolism *
}

\author{
R. Dean Wochner, Genevieve Drews, Warren Strober, \\ and Thomas A. Waldmann $\dagger$ \\ (From the Metabolism Service, National Cancer Institute, and the Medical Neurology Branch, \\ National Institute of Neurological Diseases and Blindness, Bethesda, Md.)
}

Myotonic dystrophy is a hereditary progressive muscular abnormality with dominant transmittance that was first proposed as a separate entity by Batten and Gibb (1) and by Steinert (2) in 1909. The muscular abnormality that is the dominant feature of the disease is characterized by weakness, wasting, and myotonia, especially of the facial, neck, and distal musculature. Other abnormalities frequently associated with the disease include frontal alopecia, cataracts, gonadal atrophy, low basal metabolic rate with normal thyroid function, impaired glucose tolerance, and electrocardiographic abnormalities.

Reduction in serum $\gamma$-globulin concentration has been observed in patients with myotonic dystrophy by some workers $(3,4)$ but not by others $(5)$. In 1956 Zinneman and Rotstein reported decreased $\gamma$-globulins in 7 of 12 patients with myotonic dystrophy (6). It was found that the survival halftime of ${ }^{131}$ I-labeled $\gamma$-globulin in six of these patients averaged 7.6 days compared to 10.5 days in controls, whereas the survival of albumin-131I averaged 10.2 days compared to 9.6 days in controls.

In recent years, the plasma proteins that possess immunologic activity have been the subject of intensive study. These proteins as a group are referred to as immunoglobulins and can be divided into at least three major classes. These are IgG ( $7 \mathrm{~S} \gamma_{2}$-globulins), IgA ( $\beta_{2 \Delta}$-globulins), and IgM ( $\gamma_{1}$-macroglobulins or $\beta_{2 \mathrm{M}}$-globulins). Each of these fractions possesses antibody activity and cer-

\footnotetext{
* Submitted for publication July 26, 1965; accepted November 18, 1965.

Part of this work has been published in abstract form (Clin. Res. 1965, 13, 291).

† Address requests for reprints to Dr. Thomas A. Waldmann, Metabolism Service, National Cancer Institute, Bethesda, Md. 20014.
}

tain structural features in common, but can be distinguished from the others by physicochemical and immunochemical techniques. A fourth class, IgD, has recently been described and characterized (7), although antibody activity has not as yet been demonstrated for it.

Methodology now available makes it possible to quantitate serum concentrations of each of the individual immunoglobulins and to purify and label these proteins for metabolic turnover study. The present study was undertaken to evaluate the metabolism of the major immunoglobulins and albumin in 19 patients with myotonic dystrophy as compared to 11 patients with other neuromuscular diseases and to controls. The serum concentration, total exchangeable protein pools, and rates of degradation and synthesis of these proteins were determined. We found that patients with myotonic dystrophy have a unique error in immunoglobulin metabolism, an isolated hypercatabolism of IgG.

\section{Methods}

Patients. Immunoglobulin concentrations were determined in the sera of 19 patients with myotonic dystrophy. The metabolic turnover of the immunoglobulins and albumin was studied in 15 of these subjects. The latter ranged in age from 32 to 59 years; they included 9 men and 6 women. The average duration of disease was 13 years and ranged from 7 to 31 years. Each of the.patients had myotonia, muscular weakness, and wasting, most pronounced in the facial, neck, and distal musculature. A positive family history was elicited in 14 of 15 patients, and premature balding was seen in 12 of the 15 ; in the remaining patients these findings were questionable. In 14 of 15 patients cataracts were found. Muscle biopsies were abnormal in 13 of the 15 , and electromyography demonstrated myotonia and evidence of myopathy in all of the patients. Electrocardiograms showed a high incidence of conduction defects and $\mathrm{T}$-wave abnormalities. Paper electrophoresis of the sera of the 15 patients gave 
$\gamma$-globulin concentrations averaging $0.7 \mathrm{~g}$ per $100 \mathrm{ml}$ and ranging from 0.3 to $1.3 \mathrm{~g}$ per $100 \mathrm{ml}$ (normal range, 0.6 to $2.0 \mathrm{~g}$ per $100 \mathrm{ml}$ ). The concentrations of $\alpha_{1^{-}}, \alpha_{2-}$, and $\beta$-globulins fell within normal limits in all patients. Fibrinogen, ceruloplasmin, and transferrin concentrations were likewise normal. Protein-bound iodine values were all in the normal range, but basal metabolic rates were uniformly from 10 to $30 \%$ below normal.

Protein turnover studies were also carried out in 3 patients with amyotrophic lateral sclerosis, 3 with nonmyotonic types of adult muscular dystrophy, 3 with myotonia congenita, and 2 with paramyotonia congenita. Control studies were performed in normal adult volunteers. The clinical condition of each of the patients was stable throughout the period of study. None developed clinical infection or received corticosteroid therapy, and all were maintained on an adequate diet during the period of study. All subjects had normal hepatic and renal function tests, and none had proteinuria.

Immunoglobulin concentrations. Serum immunoglobulin concentrations were determined by a recently described immunodiffusion technique (8). Samples were placed into wells of constant size in agar plates made with antiserum specific for an individual immunoglobulin incorporated into the agar.1 The diameter of the precipitin ring formed by each serum sample was compared to the diameter obtained from dilutions of a reference standard. ${ }^{2}$ Immunoglobulin concentrations thus obtained were compared to those of a panel of 50 control sera.

Total serum proteins were determined by a biuret reaction, and albumin concentration was determined by paper electrophoresis.

Preparation of labeled proteins. Preparations of IgG were obtained from both normal and myotonic dystrophy sera by DEAE cellulose chromatography by modifications of a technique previously described (9). Sterile serum samples obtained immediately before fractionation were dialyzed against $0.005 \mathrm{M}$ potassium phosphate, $\mathrm{pH} 8.0$. Two to three $\mathrm{ml}$ of dialyzed serum was applied to a $1-X$ $25-\mathrm{cm}$ column containing DEAE cellulose equilibrated with $0.005 \mathrm{M}$ potassium phosphate at $\mathrm{pH} 8.0$. Whereas other serum proteins are retained by the column under these conditions, IgG does not adhere to the adsorbent. Preparations of $\mathrm{IgG}$ thus obtained were consistently found to be immunochemically pure.

IgM was obtained by block electrophoresis followed by gel filtration, as previously described (10), with serum obtained from the same normal donor used in preparation of normal IgG. Electrophoresis was carried out for 18 hours in $\mathrm{pH} 8.6$ sodium barbital buffer with polyvinylchloride particles ${ }^{8}$ and polyvinylchloride-polyvinylacetate copolymer ${ }^{4}$ as supporting media. The gamma

1 Immunoplates, Hyland Laboratories, Los Angeles, Calif.

2 Kindly supplied by Drs. John L. Fahey and Eugene McKelvey.

${ }^{3}$ Geon resin, B. F. Goodrich Co., Niagara Falls, N. Y.

4 Pevikon, Superfosfat, Fabrika, Aktiebolog, Stockholm, Sweden. region was eluted, concentrated, and dialyzed against 1.0 $\mathrm{M} \mathrm{NaCl}, 0.1 \mathrm{M}$ Tris buffer, at $\mathrm{pH}$ 8. It was then applied to a 2- $\times 120-\mathrm{cm}$ column of Sephadex G-200,5 equilibrated with the $\mathrm{pH} 8$ Tris $\mathrm{NaCl}$ buffer. The ascending limb of the first protein peak obtained in the effluent was concentrated by ultrafiltration and found to contain pure IgM by Ouchterlony analysis.

The serum used in preparation of $\operatorname{IgA}{ }^{\circ}$ was obtained from a patient with markedly elevated serum $\operatorname{IgA}$ concentration ( $2 \mathrm{~g}$ per $100 \mathrm{ml}$ ), all of type lambda $\mathrm{L}$ chain specificity. This elevation has been observed for 7 years without additional evidence of myeloma or other neoplastic disease. The details of preparation and characterization of the $\operatorname{IgA}$ are described elsewhere (11). Two IgA preparations were used for metabolic turnover. The first of these contained $85 \% \mathrm{IgA}$ and approximately $15 \%$ IgG as a contaminant, and the second contained approximately $90 \% \mathrm{IgA}$ and $10 \%$ transferrin as a contaminant. These preparations were labeled with ${ }^{120} \mathrm{I}$ and ${ }^{181} \mathrm{I}$, respectively, and studied simultaneously.

Iodination of each of the above preparations and serum albumin 7 was performed with either ${ }^{121} \mathrm{I}$ or ${ }^{128} \mathrm{I}$ by the iodine monochloride technique of $\mathrm{McF}$ arlane (12). All preparations were calculated to have an average of less than one atom of iodine per molecule of protein in the final product. This product contained less than $1 \%$ nonprecipitable radioactivity. Normal human albumin was added to each preparation to prevent damage to the protein by self-irradiation, and the mixture was sterilized by filtration. Albumin- ${ }^{51} \mathrm{Cr}$ and $\mathrm{IgG}-{ }^{51} \mathrm{Cr}$ were prepared with ${ }^{51} \mathrm{CrCl}_{8}$ by a previously described technique (13).

Study protocol. Each patient was admitted to the National Cancer Institute or the National Institute of Neurological Diseases and Blindness during the study period. Ten drops of Lugol's solution was administered three times daily throughout the study period to prevent thyroidal uptake of the released isotope. Serum immunoglobulin concentrations and albumin concentrations were obtained at intervals throughout the study period to verify that each patient was in a steady state. Turnover studies of the protein preparations were done either simultaneously or sequentially. From 10 to $50 \mu \mathrm{c}$ of the iodinated proteins was administered intravenously from a calibrated syringe, and serum samples were obtained 10 minutes after administration and daily thereafter. Stool specimens and urine were collected in 24-hour lots. Serum and urine samples were counted with appropriate standards to within $\pm 3 \%$ counting error in an automatic gamma ray well type scintillation counter with a thalliumactivated sodium iodide crystal. When two isotopes were studied simultaneously, they were differentiated with a pulse height analyzer.

The patients were evaluated for gastrointestinal loss of protein with albumin-" $\mathrm{Cr}$ according to methods previously described (13). From 10 to $30 \mu \mathrm{c}$ of albumin- ${ }^{\circ 1} \mathrm{Cr}$

\footnotetext{
o Pharmacia Fine Chemicals, New York, N. Y.

6 Kindly supplied by Dr. Alan Solomon.

7. Cohn Fraction V, Cutter Laboratories, Berkeley, Calif.
} 
was administered intravenously, and subsequent daily serum and stool collections were made as above. Stools were brought to a constant volume, homogenized, and counted with appropriate standards in a gamma ray bulk counter employing two 2 -inch thallium-activated sodium iodide crystals.

Calculation of data. The turnovers of the iodinated proteins were analyzed according to modification of the methods of Berson, Yalow, Schreiber, and Post (14) and Pearson, Veall, and Vetter (15). The calculations are summarized by the following equations: Plasma volume (milliliters per kilogram) = radioactivity administered/ [radioactivity per milliliter plasma at 10 minutes $\times$ body weight (kilograms)]. Radioactivity retained in the body $=$ radioactivity administered minus cumulative radioactivity excreted.

Plots of the plasma radioactivity and the total radioactivity retained in the body were constructed on semilogarithmic graph paper, and the survival half-times of the labeled proteins were determined graphically. Fraction of the body protein that is intravascular = (plasma volume $X$ plasma radioactivity per milliliter)/radioactivity retained in body.

This fraction was determined after equilibration of the labeled protein among the body compartments was complete. Total circulating protein $=$ plasma volume $X$ plasma concentration of the protein. Total exchangeable pool of the protein $=$ total circulating protein/fraction of the protein that is intravascular. Fraction of circulating protein catabolized per day = radioactivity excreted in each 24-hour period/mean circulating radioactivity during the same period.

This fraction was determined for each day, and the mean value for days 3 to 15 was used in the following calculation: turnover rate $=$ total circulating protein $\times$ fraction of the circulating protein catabolized per day.
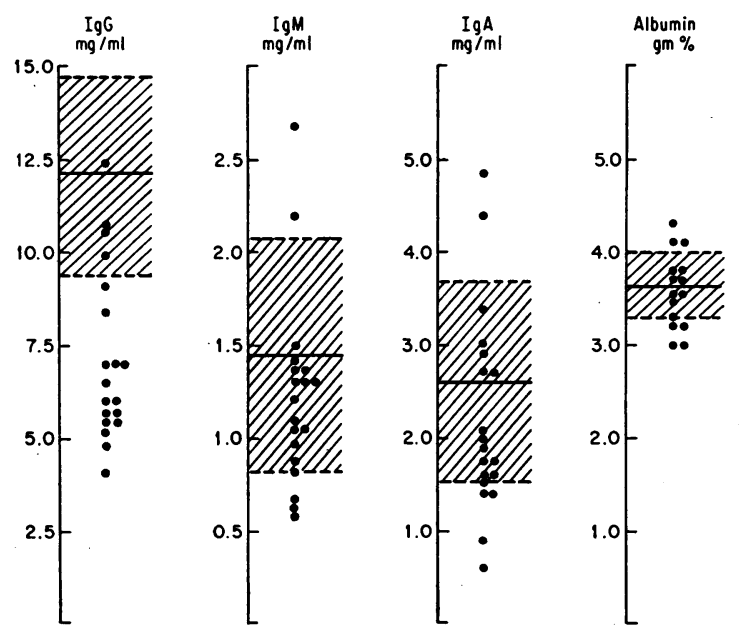

Fig. 1. Serum concentrations of immunoglobulins AND ALBUMIN IN PATIENTS WITH MYOTONIC DYSTROPHY. The means of values from 50 control sera are indicated by the solid lines and $1 \mathrm{SD}$ by the hatched area.
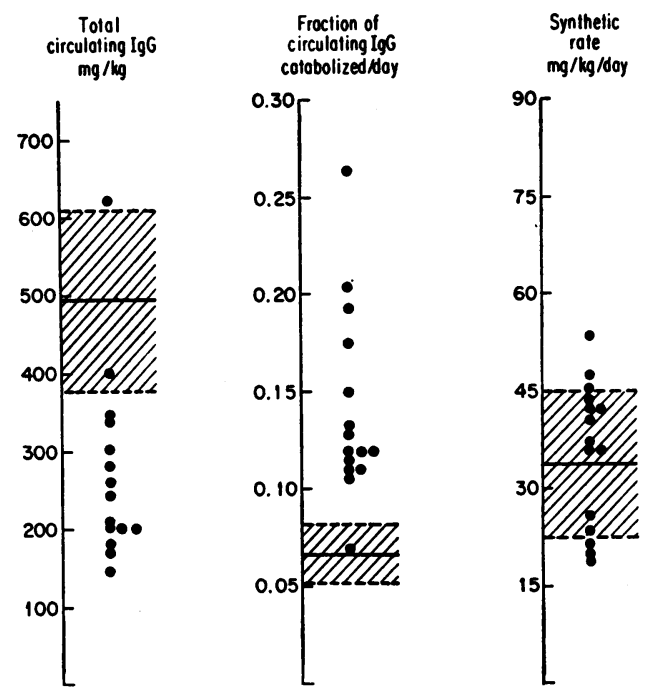

Fig. 2. Metabolism of IgG in patients with aryoTONIC DYSTROPHY. The mean values obtained from studies in 23 normal subjects are indicated by the solid lines and $1 \mathrm{SD}$ by the hatched area.

Since the concentration of each of the plasma proteins studied remained constant throughout the period of study, the assumption of a steady state was considered to be valid, and the synthetic rates for the proteins were considered to be equal to the turnover rates.

The albumin $-{ }^{51} \mathrm{Cr}$ results are expressed both as the per cent of injected isotope recovered in the feces during the first 4 days after injection and as the gastrointestinal clearance of albumin- ${ }^{-1} \mathrm{Cr}$ determined during the period of days 2 to 10 . The calculations are summarized below: Gastrointestinal clearance of albumin- ${ }^{\text {"I }} \mathrm{Cr}$ (milliliters per day) $=$ radioactivity excreted in the stool per 24-hour pe$\mathrm{riod} /$ mean radioactivity per milliliter plasma 1 day before collection period. This value assumes a transit time of approximately 1 day between any secretion of labeled protein into the gastrointestinal tract and its appearance in the stool. The daily gastrointestinal loss of albumin is then expressed as a fraction of the circulating protein pool, using the plasma volume determined by separate study with an iodinated protein. Gastrointestinal clearance (fraction of circulating pool cleared per day) = milliliters cleared per day/plasma volume.

\section{Results}

The serum concentrations of albumin and the immunoglobulins in 19 patients with myotonic dystrophy are shown in Figure 1. The albumin, $\operatorname{Ig} \mathrm{A}$, and $\operatorname{Ig} \mathrm{M}$ concentrations were within normal limits, although the IgM concentrations tended to lie between the mean and $1 \mathrm{SD}$ below the mean of 50 normal sera. In contrast, IgG levels were distinctly reduced with a mean of $7.2 \mathrm{mg}$ per $\mathrm{ml}$ 
TABLE I

IgGlmetabolism in patients with myotonic dystrophy and other neuromuscular disorders

\begin{tabular}{|c|c|c|c|c|c|c|c|}
\hline $\begin{array}{l}\text { Patient and } \\
\text { diagnosis }\end{array}$ & $\begin{array}{l}\text { Serum } \\
\text { IgG } \\
\text { concen- } \\
\text { tration }\end{array}$ & $\begin{array}{l}\text { Plasma } \\
\text { volume }\end{array}$ & $\begin{array}{c}\text { Total } \\
\text { circu- } \\
\text { lating } \\
\text { IgG }\end{array}$ & $\begin{array}{c}\text { Total } \\
\text { exchange- } \\
\text { able } \\
\text { IgG }\end{array}$ & 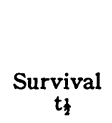 & $\begin{array}{l}\text { Fraction of } \\
\text { circulat- } \\
\text { ing IgG } \\
\text { catabolized } \\
\text { per day }\end{array}$ & $\underset{\text { Turnover }}{\text { rate }}$ \\
\hline & $m g / m l$ & $\mathrm{ml} / \mathrm{kg}$ & $m g / k g$ & $\mathrm{mg} / \mathrm{kg}$ & days & & $\mathrm{mg} / \mathrm{kg} / \mathrm{day}$ \\
\hline $\begin{array}{r}\text { Controls }(23) \\
\text { Mean } \\
\pm \text { SD }\end{array}$ & $\begin{array}{r}12.1 \\
\pm 2.6\end{array}$ & $\begin{array}{r}42.0 \\
\pm 5.8\end{array}$ & $\begin{array}{r}494 \\
\pm 116\end{array}$ & $\begin{array}{r}1,090 \\
\pm 263\end{array}$ & $\begin{array}{r}22.9 \\
\pm 4.0\end{array}$ & $\begin{array}{r}0.0668 \\
\pm 0.0152\end{array}$ & $\begin{array}{r}33.7 \\
\pm 11.2\end{array}$ \\
\hline \multicolumn{8}{|l|}{$\begin{array}{c}\text { Myotonic } \\
\text { dystrophy }\end{array}$} \\
\hline WTJ & 4.8 & 30 & 140 & 320 & 9.7 & 0.134 & 19 \\
\hline GW & 5.2 & 38 & 200 & 560 & 15.8 & 0.130 & 26 \\
\hline WAJ & 5.5 & 36 & 200 & 460 & 7.0 & 0.203 & 41 \\
\hline MW & 5.7 & 35 & 200 & 340 & 9.5 & 0.118 & 24 \\
\hline NL & 5.7 & 32 & 180 & 560 & 7.4 & 0.263 & 47 \\
\hline MH & 5.9 & 30 & 180 & 450 & 10.9 & 0.114 & 20 \\
\hline DJ & 6.1 & 49 & 300 & 710 & 12.5 & 0.119 & 36 \\
\hline $\mathbf{R M}$ & 6.9 & 38 & 260 & 580 & 9.9 & 0.175 & 46 \\
\hline LF & 7.0 & 29 & 200 & 510 & 16.3 & 0.106 & 22 \\
\hline $\mathrm{JL}$ & 7.0 & 35 & 240 & 580 & 7.0 & 0.149 & 36 \\
\hline TL & 9.1 & 38 & 350 & 840 & 13.0 & 0.119 & 42 \\
\hline EM & 9.9 & 34 & 340 & 840 & 10.6 & 0.109 & 37 \\
\hline $\mathrm{JHC}$ & 10.6 & 26 & 280 & 710 & 8.0 & 0.192 & 54 \\
\hline WF & 10.7 & 58 & 620 & 1,100 & 18.7 & 0.068 & 42 \\
\hline JDC & 12.4 & 32 & 400 & 1,100 & 15.2 & 0.108 & 43 \\
\hline $\begin{array}{l}\text { Mean } \\
\pm \mathrm{SD}\end{array}$ & $\begin{array}{r}7.5 \\
\pm 2.4\end{array}$ & $\begin{array}{r}36.0 \\
\pm 5.3\end{array}$ & $\begin{array}{r}273 \\
\pm 121\end{array}$ & $\begin{array}{r}642 \\
\pm \quad 78\end{array}$ & $\begin{array}{r}11.4 \\
\pm \quad 3.5\end{array}$ & $\begin{array}{r}0.140 \\
\pm 0.043\end{array}$ & $\begin{array}{r}35.7 \\
\pm 10.9\end{array}$ \\
\hline \multicolumn{8}{|l|}{$\begin{array}{c}\text { Muscular } \\
\text { dystrophy }\end{array}$} \\
\hline $\mathrm{FE}$ & 10.9 & 36.4 & 400 & 1,200 & 23.8 & 0.0881 & 35 \\
\hline $\mathbf{C M}$ & 9.7 & 49.5 & 480 & 930 & 24.0 & 0.0564 & 27 \\
\hline EC & 15.6 & 34.9 & 540 & 1,100 & 16.0 & 0.0866 & 47 \\
\hline \multicolumn{8}{|l|}{$\begin{array}{l}\text { Amyotrophic } \\
\text { lateral } \\
\text { sclerosis }\end{array}$} \\
\hline JN & 9.0 & 38 & 350 & 890 & 24.1 & 0.0717 & 26 \\
\hline LB & 6.5 & 39 & 250 & 460 & 23.9 & 0.0532 & 13 \\
\hline EC* & 9.2 & 44 & 400 & 890 & 21.0 & 0.0655 & 26 \\
\hline \multicolumn{8}{|l|}{$\begin{array}{c}\text { Myotonia } \\
\text { congenita }\end{array}$} \\
\hline ME & 9.5 & 34 & 320 & 730 & 18.0 & 0.0875 & 28 \\
\hline EM & 9.4 & 42 & 390 & 730 & 16.0 & 0.0808 & 32 \\
\hline $\mathrm{CZ}$ & 10.8 & 41 & 440 & 880 & 22.0 & 0.0730 & 32 \\
\hline \multicolumn{8}{|l|}{$\begin{array}{c}\text { Paramyotonia } \\
\text { congenita }\end{array}$} \\
\hline BA & 10.7 & 33 & 350 & 740 & 24.5 & 0.0600 & 21 \\
\hline FW & 7.2 & 44 & 320 & 660 & 21.7 & 0.0666 & 21 \\
\hline
\end{tabular}

* Turnover performed with labeled IgG that had been incubated in serum from a patient with myotonic dystrophy.

compared to a mean of $12.1 \mathrm{mg}$ per $\mathrm{ml}$ in control sera $(p<0.001)$. The concentrations of 15 of the 19 patients were below $1 \mathrm{SD}$ from the normal mean. Both the total circulating and total exchangeable IgG pools were similarly reduced $(p<0.001)$. The intravascular to extravascular ratios were normal. The survival of ${ }^{125} \mathrm{I}$-labeled IgG was markedly shortened in the patients with myotonic dystrophy. Survival half-times averaged 11.4 days, compared to an average of 22.9 days in a group of 23 normals (Table I). An average of
$14.0 \%$ of the circulating IgG was catabolized daily in the patients with myotonic dystrophy, compared to $6.68 \pm 1.52 \%$ in the controls $(p<0.001)$. The rate of IgG synthesis was normal in the patients with myotonic dystrophy (Figure 2 ). Thus, the reduction in serum concentration and body pool size of IgG was due solely to the shortened survival of the protein. No abnormality of IgG metabolism was demonstrated in the 11 patients studied with other neuromuscular disorders ( $\mathrm{Ta}$ ble I). 
TABLE II

Albumin metabolism in patients with myotonic dystrophy

\begin{tabular}{|c|c|c|c|c|c|c|c|c|c|}
\hline \multirow[b]{2}{*}{ Subject } & \multirow[b]{2}{*}{$\begin{array}{l}\text { Serum } \\
\text { albumin } \\
\text { concen- } \\
\text { tration }\end{array}$} & \multicolumn{6}{|c|}{ Albumin- $I^{12 n}$ studies } & \multicolumn{2}{|c|}{ Albumin-51Cr studies } \\
\hline & & $\begin{array}{l}\text { Plasma } \\
\text { volume }\end{array}$ & $\begin{array}{c}\text { Total } \\
\text { circulat- } \\
\text { ing } \\
\text { albumin }\end{array}$ & $\begin{array}{c}\text { Total } \\
\text { exchange- } \\
\text { able } \\
\text { albumin }\end{array}$ & $\begin{array}{c}\text { Survival } \\
\mathrm{t}\end{array}$ & $\begin{array}{l}\text { Fraction of } \\
\text { circulating } \\
\text { albumin } \\
\text { catabolized } \\
\text { per day }\end{array}$ & $\begin{array}{l}\text { Turnover } \\
\text { rate }\end{array}$ & $\begin{array}{l}\% \text { injected } \\
\text { dose in } \\
\text { first } 4 \\
\text { days stools }\end{array}$ & $\begin{array}{l}\text { Gastrointestinal } \\
\text { clearance } \\
\text { (fraction of } \\
\text { circulating } \\
\text { albumin cleared } \\
\text { per day) }\end{array}$ \\
\hline Controls (10) & $\mathrm{g} / 100 \mathrm{ml}$ & $\mathrm{ml} / \mathrm{kg}$ & $\mathrm{g} / \mathrm{kg}$ & $\mathrm{g} / \mathrm{kg}$ & days & & $\mathrm{g} / \mathrm{kg} /$ day & & \\
\hline $\begin{array}{l}\text { Mean } \\
\text { Range }\end{array}$ & $\begin{array}{c}4.0 \\
(3.5-4.6)\end{array}$ & $\begin{array}{c}42 \\
(35-50)\end{array}$ & $\begin{array}{c}1.7 \\
(1.5-2.0)\end{array}$ & $\begin{array}{c}4.1 \\
(3.6-4.6)\end{array}$ & $\begin{array}{c}17 \\
(13-20)\end{array}$ & $\begin{array}{c}0.10 \\
(0.087-0.132)\end{array}$ & $\begin{array}{c}0.17 \\
(0.15-0.20)\end{array}$ & $\begin{array}{c}0.22 \\
(0-0.7)\end{array}$ & $\begin{array}{c}0.0058 \\
(0.001-0.017)\end{array}$ \\
\hline $\begin{array}{c}\text { Myotonic } \\
\text { dystrophy* } \\
\text { Mean } \\
\text { Range }\end{array}$ & $\begin{array}{c}3.6 \\
(3.0-4.3)\end{array}$ & $\begin{array}{c}37 \\
(30-46)\end{array}$ & $\begin{array}{c}1.4 \\
(0.9-2.0)\end{array}$ & $\begin{array}{c}4.0 \\
(2.6-5.3)\end{array}$ & $\begin{array}{c}17.5 \\
(13-26)\end{array}$ & $\begin{array}{c}0.12 \\
(0.090-0.175)\end{array}$ & $\begin{array}{c}0.17 \\
(0.10-0.21)\end{array}$ & $\begin{array}{c}0.28 \\
(0.2-0.92)\end{array}$ & $\begin{array}{c}0.007 \\
(0.001-0.017)\end{array}$ \\
\hline
\end{tabular}

* Serum concentration determined in 13 patients, iodinated-albumin studies in 9 patients, and chromium-albumin studies in 10 patients. All 15 patients had either an iodinated-albumin or chromium-albumin study or both.

TABLE III

IgM metabolism in patients with myotonic dystrophy

\begin{tabular}{|c|c|c|c|c|c|c|c|}
\hline Subject & $\begin{array}{l}\text { Serum } \\
\text { IgM } \\
\text { concen- } \\
\text { tration }\end{array}$ & $\begin{array}{l}\text { Plasma } \\
\text { volume }\end{array}$ & $\begin{array}{l}\text { Total } \\
\text { circulating } \\
\text { IgM }\end{array}$ & $\begin{array}{l}\text { Total ex- } \\
\text { changeable } \\
\text { IgM }\end{array}$ & $\underset{t}{\text { Survival }}$ & $\begin{array}{c}\text { Fraction of } \\
\text { circulating } \\
\text { IgM } \\
\text { catabolized } \\
\text { per day }\end{array}$ & $\begin{array}{l}\text { Turnover } \\
\text { rate }\end{array}$ \\
\hline Controls (10) & $m g / m l$ & $\mathrm{ml} / \mathrm{kg}$ & $\mathrm{mg} / \mathrm{kg}$ & $m g / k g$ & days & & $\mathrm{mg} / \mathrm{kg} / \mathrm{day}$ \\
\hline $\begin{array}{l}\text { Mean } \\
\pm \text { SD }\end{array}$ & $\begin{array}{r}1.45 \\
\pm 0.63\end{array}$ & $\begin{array}{r}38.5 \\
\pm 8.7\end{array}$ & $\begin{array}{r}50.1 \\
\pm 25.2\end{array}$ & $\begin{array}{r}66.0 \\
\pm 39.6\end{array}$ & $\begin{array}{r}5.4 \\
\pm 1.0\end{array}$ & $\begin{array}{r}0.172 \\
\pm 0.041\end{array}$ & $\begin{array}{r}8.96 \\
\pm 6.2\end{array}$ \\
\hline $\begin{array}{c}\text { Myotonic } \\
\text { dystrophy }\end{array}$ & & & & & & & \\
\hline $\begin{array}{l}\text { WTJ } \\
\text { GW }\end{array}$ & $\begin{array}{l}1.51 \\
1.08\end{array}$ & $\begin{array}{l}30 \\
25\end{array}$ & $\begin{array}{l}45 \\
27\end{array}$ & $\begin{array}{l}63 \\
39\end{array}$ & $\begin{array}{l}4.8 \\
4.3\end{array}$ & $\begin{array}{l}0.204 \\
0.230\end{array}$ & $\begin{array}{l}9.2 \\
6.2\end{array}$ \\
\hline NL & 1.30 & 32 & 41 & 70 & 7.6 & 0.156 & 6.4 \\
\hline DJ & 1.29 & 54 & 70 & 130 & 7.5 & 0.168 & 12.0 \\
\hline JL & 2.67 & 35 & 94 & 170 & 6.6 & 0.185 & 17.0 \\
\hline TL & 2.19 & 43 & 94 & 110 & 4.4 & 0.190 & 18.0 \\
\hline EM & 1.30 & 25 & 32 & 59 & 6.1 & 0.212 & 6.8 \\
\hline WF & 0.82 & 64 & 52 & 69 & 7.0 & 0.130 & 6.8 \\
\hline JDC & 0.97 & 41 & 40 & 50 & 8.4 & 0.104 & 4.1 \\
\hline
\end{tabular}

TABLE IV

IgA metabolism in three patients with myotonic dystrophy

\begin{tabular}{|c|c|c|c|c|c|c|c|}
\hline Subject & $\begin{array}{c}\text { Serum } \\
\text { IgA } \\
\text { concen- } \\
\text { tration }\end{array}$ & $\begin{array}{l}\text { Plasma } \\
\text { volume }\end{array}$ & $\begin{array}{c}\text { Total } \\
\text { circulat- } \\
\text { ing } \\
\text { IgA }\end{array}$ & $\begin{array}{c}\text { Total ex- } \\
\text { changeable } \\
\text { IgA }\end{array}$ & $\underset{t}{\text { Survival }}$ & $\begin{array}{c}\text { Fraction of } \\
\text { circulating } \\
\text { IgA } \\
\text { catabolized } \\
\text { per day }\end{array}$ & $\begin{array}{c}\text { Turnover } \\
\text { rate }\end{array}$ \\
\hline & $m g / m l$ & $\mathrm{ml} / \mathrm{kg}$ & $\mathrm{mg} / \mathrm{kg}$ & $\mathrm{mg} / \mathrm{kg}$ & days & & $\mathrm{mg} / \mathrm{kg} / \mathrm{day}$ \\
\hline $\begin{array}{l}\text { Mean } \\
\text { Range }\end{array}$ & $\begin{array}{c}2.53 \\
(0.2-5.0)\end{array}$ & $\begin{array}{c}38.3 \\
(32-44)\end{array}$ & $\begin{array}{c}95.4 \\
(8-190)\end{array}$ & $\begin{array}{c}209 \\
(20-400)\end{array}$ & $\begin{array}{c}6.4 \\
(5.4-8.2)\end{array}$ & $\begin{array}{c}0.219 \\
(0.180-0.245)\end{array}$ & $\begin{array}{c}21.6 \\
(2-44)\end{array}$ \\
\hline $\begin{array}{c}\text { Myotonic } \\
\text { dystrophy } \\
\text { WTJ } \\
\text { WAJ } \\
\text { JHC }\end{array}$ & $\begin{array}{l}1.6 \\
3.4 \\
2.7\end{array}$ & $\begin{array}{l}33 \\
44 \\
33\end{array}$ & $\begin{array}{r}53 \\
150 \\
89\end{array}$ & $\begin{array}{r}91 \\
340 \\
190\end{array}$ & $\begin{array}{l}5.8 \\
6.5 \\
5.7\end{array}$ & $\begin{array}{l}0.203 \\
0.192 \\
0.224\end{array}$ & $\begin{array}{l}11 \\
29 \\
20\end{array}$ \\
\hline
\end{tabular}




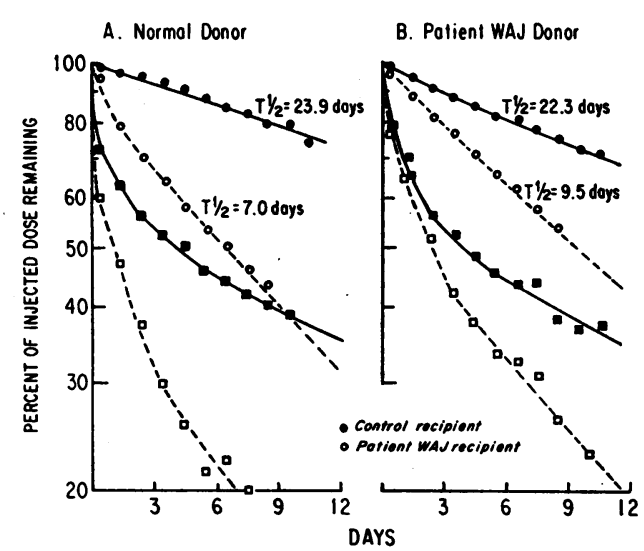

Fig. 3. The metabolism of IgG. The metabolism of IgG from a normal donor is shown in panel $A$. The survival of this material in a normal recipient indicated with solid lines and solid symbols is normal with a $t_{1}$ of 23.9 days and markedly shortened to 7 days in a patient (WAJ) with myotonic dystrophy indicated by the dashed lines and open symbols. The per cent of the injected dose remaining in the serum is indicated by square symbols and that remaining in the body by the circles. The survival of IgG from patient WAJ (panel B) was normal in the control subject but markedly shortened in patient WAJ.
The total circulating and exchangeable pools, the survival half-times, and the turnover rates of albumin, $\operatorname{IgM}$, and $\operatorname{IgA}$ in subjects with myotonic dystrophy were comparable to those in control subjects (Tables II, III, and IV). No pathologic gastrointestinal loss of protein was demonstrated with ${ }^{51} \mathrm{Cr}$-labeled albumin, and in one subject with ${ }^{51} \mathrm{Cr}$-labeled IgG.

Four IgG preparations were obtained from 4 patients with myotonic dystrophy. Each preparation was labeled and injected into the patient from whom it had been obtained and into a normal control subject. This IgG was catabolized normally in the controls, but in the patients with myotonic dystrophy it was catabolized at an accelerated rate comparable to that of IgG from a normal donor (Figure 3 and Table V). Thus, host factors appear to be responsible for the accelerated breakdown of $\operatorname{IgG}$, rather than an abnormality of the IgG itself.

\section{Discussion}

Serum IgG concentrations have been demonstrated to be significantly reduced in the group of

TABLE $\mathbf{v}$

Comparison of IgG preparations in patients with myotonic dystrophy and in controls

\begin{tabular}{|c|c|c|c|c|c|c|c|c|}
\hline $\begin{array}{l}\text { Recipient and } \\
\text { diagnosis }\end{array}$ & $\begin{array}{l}\text { Source of } \\
\text { IgG }\end{array}$ & $\begin{array}{l}\text { Serum } \\
\text { IgG } \\
\text { concen- } \\
\text { tration }\end{array}$ & $\begin{array}{l}\text { Plasma } \\
\text { volume }\end{array}$ & $\begin{array}{l}\text { Total } \\
\text { circu- } \\
\text { lating } \\
\text { IgG }\end{array}$ & $\begin{array}{l}\text { Total ex- } \\
\text { changeable } \\
\text { IgG }\end{array}$ & $\underset{t}{\text { Survival }}$ & $\begin{array}{c}\text { Fraction of } \\
\text { circulating } \\
\text { IgG } \\
\text { catabolized } \\
\text { per day }\end{array}$ & $\begin{array}{l}\text { Turnover } \\
\text { rate }\end{array}$ \\
\hline \multirow{3}{*}{$\begin{array}{l}\text { WAJ (Myotonic } \\
\text { dystrophy) }\end{array}$} & & $m g / m l$ & $m l / k g$ & $m g / k g$ & $m g / k g$ & days & & $m g / k g / d a y$ \\
\hline & $\begin{array}{l}\text { Normal } \\
\text { donor }\end{array}$ & 5.5 & 36 & 200 & 460 & 7.0 & 0.203 & 41 \\
\hline & Patient WAJ & 5.5 & 41 & 230 & 480 & 9.5 & 0.167 & 38 \\
\hline \multirow[t]{2}{*}{$\begin{array}{c}\text { JHC (Myotonic } \\
\text { dystrophy) }\end{array}$} & $\begin{array}{c}\text { Normal } \\
\text { donor }\end{array}$ & 10.6 & 26 & 280 & 710 & 8.0 & 0.192 & 54 \\
\hline & Patient JHC & 10.6 & 23 & 240 & 480 & 6.2 & 0.208 & 50 \\
\hline \multirow{2}{*}{$\begin{array}{c}\text { TL (Myotonic } \\
\text { dystrophy) }\end{array}$} & Normal & . & & & & & & \\
\hline & $\begin{array}{c}\text { donor } \\
\text { Patient TL }\end{array}$ & $\begin{array}{l}9.1 \\
9.1\end{array}$ & $\begin{array}{l}38 \\
44\end{array}$ & $\begin{array}{l}350 \\
400\end{array}$ & $\begin{array}{l}840 \\
900\end{array}$ & $\begin{array}{l}13.0 \\
16.6\end{array}$ & $\begin{array}{l}0.119 \\
0.094\end{array}$ & $\begin{array}{l}42 \\
38\end{array}$ \\
\hline \multirow{3}{*}{ WTJ (Myotonic } & Normal & & & & & & & \\
\hline & donor & 4.8 & 30 & 140 & 320 & 9.7 & 0.134 & 19 \\
\hline & Patient WTJ & 4.8 & 34 & 160 & 480 & 13.2 & 0.130 & 21 \\
\hline \multirow{3}{*}{$\begin{array}{r}\text { LB (Amyotrophic } \\
\text { lateral sclerosis) }\end{array}$} & & & & & & & & \\
\hline & $\begin{array}{c}\text { Normal } \\
\text { donor }\end{array}$ & 6.5 & 39 & 250 & 460 & 23.9 & 0.053 & 13 \\
\hline & Patient WAJ & 6.5 & 37 & 240 & 450 & 22.3 & 0.058 & 14 \\
\hline \multirow[t]{2}{*}{ JV (Normal) } & Patient JHC & 14.1 & 36 & 510 & 940 & 27.8 & 0.046 & 23 \\
\hline & Patient TL & 14.1 & 38 & 540 & 1,100 & 30.5 & 0.046 & 25 \\
\hline \multirow{2}{*}{$\begin{array}{l}\text { AS (Normal) } \\
\text { Controls (23) }\end{array}$} & Patient WTJ & 13.7 & 38 & 520 & 1,100 & 20.0 & 0.063 & 33 \\
\hline & $\begin{array}{c}\text { Normal } \\
\text { donor }\end{array}$ & 12.1 & 42.0 & 494 & 1,090 & 22.9 & 0.0668 & 33.7 \\
\hline Mean $\pm \mathrm{SD}$ & & \pm 2.6 & \pm 5.8 & \pm 116 & \pm 263 & \pm 4.0 & \pm 0.0152 & \pm 11.2 \\
\hline
\end{tabular}


patients with myotonic dystrophy. The concentrations of albumin, IgA, and IgM were within normal limits.

Reduction of serum IgG concentration has been observed in a variety of other clinical situations. There are three major factors that determine the concentration of a protein within the plasma. They are the rate of synthesis, the distribution in the body, and the rate of breakdown of the protein. Defective synthesis of IgG and the other immunoglobulins has been demonstrated to be the fundamental defect in congenital hypogammaglobulinemia of either the sex-linked or sporadic type, and acquired hypogammaglobulinemia of idiopathic origin, or that associated with lymphoreticular malignancies (16-21). Defective IgG synthesis has also been demonstrated in patients with dysgammaglobulinemia who have reduction in serum IgG and IgA with normal or increased levels of IgM (22). In these patients with defective IgG synthesis, the survival of IgG has been normal or prolonged.

Reduction of plasma IgG concentration may also result from an altered distribution of the protein. This mechanism may be observed in patients with markedly increased plasma volumes or in those with accumulation of protein in extravascular sites, as in malignant effusions.

Hypogammaglobulinemia associated with apparent shortened survival of IgG has been observed in patients with protein-losing enteropathy and with nephrosis $(16,18)$. These syndromes are characterized by bulk loss of the plasma proteins into the urine or gastrointestinal tract. The IgG metabolism observed in myotonic dystrophy is not comparable to that of these protein-losing disorders, since the survival of $\operatorname{IgA}, \operatorname{IgM}$, and albumin was normal. In addition, no urinary protein was observed in these patients, and tests for gastrointestinal protein loss with ${ }^{51} \mathrm{Cr}$-labeled albumin and IgG were negative. Thus, the defective metabolism observed in myotonic dystrophy does not represent an actual loss of plasma proteins from the body, but rather appears to be an endogenous defect of catabolism specific for the single protein IgG.

A number of other inherited diseases have been associated with significant reduction in one or more plasma proteins. However, in each instance studied, the basic disorder has been that of defective synthesis, with normal or prolonged survival of the affected proteins. Normal survival has been observed for fibrinogen in afibrinogenemia (23), ceruloplasmin in Wilson's disease (24), and IgM and $\operatorname{IgA}$ in agammaglobulinemia $(10,25)$. The survival of albumin in analbuminemia (26-28) and IgG in agammaglobulinemia (16) has been prolonged. Thus, myotonic dystrophy is the first disease found to have an associated deficiency of a plasma protein caused by accelerated breakdown specific for the protein.

Consideration of the cause of the observed phenomenon must remain speculative at this time. The evidence presented here indicates that the defect is a phenomenon of the host and not an abnormality of IgG itself. IgG from a normal donor had a shortened survival in the patients with myotonic dystrophy, and the preparations of IgG isolated from 4 patients with myotonic dystrophy had a normal survival in controls. Since the survival of IgM and IgA was normal in patients with myotonic dystrophy, the abnormality is related to the portion of the protein molecule that is specific for IgG. Each of the immunoglobulins is composed of two pairs of polypeptide chains, the $\mathrm{H}$ and $\mathrm{L}$ chains, linked by disulfide bonds. The $\mathrm{L}$ chains are the same among classes of immunoglobulins, whereas the $\mathrm{H}$ chains differ among the classes. Thus, the metabolic error in patients with myotonic dystrophy is specifically directed toward the $\mathrm{H}$ chain of IgG.

Other unique features of IgG metabolism have been described that appear to be specific for IgG and are therefore determined by its $H$ chain. These include preferential transport of intact IgG by the placenta $(29,30)$ and by the newborn gut in certain species (31) and also the correlation between the serum IgG concentration and the fractional rate of catabolism. Whereas fractional catabolic rates for IgG are reduced in animals or man with hypogammaglobulinemia due to defective synthesis (16), they are increased with elevated IgG levels due to chronic infection (32), liver disease $(33)$, and multiple myeloma $(9,34)$, or after infusion of $\operatorname{IgG}(35,36)$.

To explain these phenomena, Brambell, Hemmings, and Morris have recently postulated that there is within the body a saturable system of protector sites, specific for IgG (37). If a given number of IgG molecules could temporarily be bound by such a system and protected from ca- 
tabolism, increasing concentrations of IgG would result in a larger fraction of the total body IgG available for catabolism, and thus the fractional catabolic rate would be higher. The reverse would hold for a very low IgG concentration, with a relatively small fraction of the total IgG available for catabolism. These studies in myotonic dystrophy patients contain no direct evidence pertaining to this hypothesis. However, it might be observed that the extreme IgG elevations seen in patients with multiple myeloma should result in protection of only a negligible fraction of the total IgG, and catabolic rates should thus approximate a theoretical state lacking such a protective system. Yet the fractional catabolic rates of 8 of the 15 patients with myotonic dystrophy exceeded any of those seen in patients with multiple myeloma possessing such elevations (9). Thus it appears unlikely that IgG hypercatabolism in myotonic dystrophy results from an absence or abnormality of such protector sites.

It has been observed that some patients with rheumatoid arthritis catabolize ${ }^{131}$ I-labeled IgG at an accelerated rate. Some of the radioiodinated IgG in such patients was found to be associated with intermediate sedimenting complexes (38). No evidence was obtained to suggest that this is so in myotonic dystrophy. A serum sample obtained from a patient with myotonic dystrophy 18 hours after administration of labeled $\operatorname{IgG}$ was passed over a column of Sephadex G-200. The radioactivity in the effluent was found to coincide with the middle protein peak, the expected position for unaggregated IgG. An attempt was also made to demonstrate the presence in myotonic dystrophy serum of substances that might render IgG susceptible to rapid catabolism. Labeled IgG was incubated at $37^{\circ} \mathrm{C}$ overnight in $10 \mathrm{ml}$ of sterile serum from a patient with myotonic dystrophy and then injected into a subject with amyotrophic lateral sclerosis. However, the subsequent turnover was normal, with a survival half-time of 21 days and no evidence of a rapidly catabolized fraction.

Thus, although several characteristics of this host defect in IgG catabolism can be defined, its exact nature remains obscure. Until more is known of the normal mechanism of catabolism of $\mathrm{IgG}$, it is not clear whether this abnormality represents an acceleration of a normal process or the addition of a new mechanism. It is hoped that further studies of this phenomenon will shed light both on the factors affecting normal IgG catabolism and the nature of the fundamental defects in myotonic dystrophy.

\section{Summary}

The serum concentrations and metabolic turnover of each of the individual immunoglobulins and albumin have been evaluated in 15 patients with myotonic dystrophy. Concentrations of IgG were significantly reduced with a mean of $7.2 \mathrm{mg}$ per $\mathrm{ml}$ compared to $12.1 \pm 2.6 \mathrm{mg}$ per $\mathrm{ml}$ in controls. Normal serum concentrations and rates of catabolism were observed for albumin, IgM, and $\operatorname{Ig} \mathrm{A}$.

The catabolism of normal IgG was accelerated in patients with myotonic dystrophy, with survival half-times averaging 11.4 days compared to an average of 22.9 days in controls. An average of $14.0 \%$ of the circulating IgG was catabolized daily, compared to $6.68 \pm 1.52 \%$ in controls. IgG isolated from patients with myotonic dystrophy had a similar accelerated catabolism in these patients but a normal survival in controls. Since the rates of synthesis of IgG were normal, the reduced serum levels were entirely accounted for by increased breakdown. None of the 11 patients with other neuromuscular diseases had accelerated catabolism of IgG. Thus, patients with myotonic dystrophy have a unique immunoglobulin abnormality-an isolated hypercatabolism of $\operatorname{IgG}$.

\section{References}

1. Batten, F. E., and H. P. Gibb. Myotonia atrophica. Brain 1909, 32, 187.

2. Steinert, $H$. Über das klinische und anatomische Bild des Muskelschwunds der Myotoniker. Dtsch. Z. Nervenheilk. 1909, 37, 58.

3. Kuhn, V. E., and H. Weicker. Serumproteine und Lipide bei myotonischer Dystrophie. Schweiz. med. Wschr. 1957, 87, 460.

4. Lowenthal, A., and M. Van Sande. Nouvelles déterminations des fractions protéiniques dans le sérum de patients atteints d'affections musculaires. Rev. franç. Etud. clin. biol. 1956, 1, 765.

5. Oppenheimer, H., and A. T. Milhorat. Serum proteins, lipoproteins, and glycoproteins in muscular dystrophy and related diseases. Ann. N. Y. Acad. Sci. 1961, 94, 308.

6. Zinneman, H. H., and J. Rotstein. A study of gamma globulins in dystrophia myotonica. J. Lab. clin. Med. 1956, 47, 907. 
7. Rowe, D. S., and J. L. Fahey. A new class of human immunoglobulins. I. Normal serum IgD. J. exp. Med. 1965, 121, 185.

8. Fahey, J. L., and E. M. McKelvey. Quantitative determination of serum immunoglobulins in antibodyagar plates. J. Immunol. 1965, 94, 84.

9. Solomon, A., T. A. Waldmann, and J. L. Fahey. Metabolism of normal $6.6 \mathrm{~S} \gamma$-globulin in normal subjects and in patients with macroglobulinemia and multiple myeloma. J. Lab. clin. Med. 1963, $62,1$.

10. Barth, W. F., R. D. Wochner, T. A. Waldmann, and J. L. Fahey. Metabolism of human gamma macroglobulins. J. clin. Invest. 1964, 43, 1036.

11. Strober, W., R. D. Wochner, and T. A. Waldmann. In preparation.

12. McFarlane, A. S. Efficient trace-labelling of proteins with iodine. Nature (Lond.) 1958, 182, 53.

13. Waldmann, T. A. Gastrointestinal protein loss demonstrated by ${ }^{\circledR} \mathrm{Cr}$-labelled albumin. Lancet 1961, 2, 121.

14. Berson, S. A., R. S. Yalow, S. S. Schreiber, and J. Post. Tracer experiments with $\mathrm{I}^{181}$ labeled human serum albumin: distribution and degradation studies. J. clin. Invest. 1953, 32, 746.

15. Pearson, J. D., N. Veall, and H. Vetter. A practical method for plasma albumin turnover studies. Strahlentherapie 1958, 38, 290.

16. Waldmann, T. A., and P. J. Schwab. IgG (7 S gamma globulin) metabolism in hypogammaglobulinemia: studies in patients with defective gamma globulin synthesis, gastrointestinal protein loss, or both. J. clin. Invest. 1965, 44, 1523.

17. Cohen, S., and T. Freeman. Metabolic heterogeneity of human $\gamma$-globulin. Biochem. J. 1960, 76, 475.

18. Andersen, S. B. Metabolism of gammass globulin in secondary hypogammaglobulinemia. Amer. J. Med. 1963, 35, 708.

19. Martin, C. M., R. S. Gordon, W. R. Felts, and N. B. McCullough. Studies on gamma globulin. I. Distribution and metabolism of antibodies and gamma globulin in hypogammaglobulinemic patients. $\mathrm{J}$. Lab. clin. Med. 1957, 49, 607.

20. Weiner, A. S., and E. B. Gordon. Studies on the human serum gamma globulin. I. Half-life and rate of production. J. Lab. clin. Med. 1957, 49, 258.

21. Bronsky, D., A. Dubin, and D. S. Kushner. The persistence in the blood of the radioactive label of albumins, gamma globulins, and globulins of intermediate mobility. VII. Uptake and die-away plots of $\mathrm{S}^{\mathrm{s}}$ into serum albumins and gamma globulins after oral administration of labeled methionine in idiopathic hypogammaglobulinemia and multiple myeloma. J. Lab. clin. Med. 1959, 53, 665.

22. Barth, W. F., R. Asofsky, T. J. Liddy, Y. Tanaka, D. S. Rowe, and J. L. Fahey. An antibody deficiency syndrome: selective immunoglobulin deficiency with reduced synthesis of gamma and alpha immunoglobulin polypeptide chains. Amer. J. Med. 1965, 39, 319.

23. Rausen, A. R., A. Cruchaud, C. W. McMillan, and D. Gitlin. A study of fibrinogen turnover in classical hemophilia and congenital afibrinogenemia. Blood 1961, 18, 710.

24. Sternlieb, I., A. G. Morell, W. D. Tucker, M. W. Greene, and I. H. Scheinberg. The incorporation of copper into ceruloplasmin in vivo: studies with copper $^{\text {et }}$ and copper $^{\text {et. }}$ J. clin. Invest. 1961, 40, 1834.

25. Solomon, A., and T. B. Tomasi, Jr. Metabolism of IgA $\left(\beta_{2} A\right)$ globulin. Clin. Res. 1964, 12, 452.

26. Waldmann, T. A., R. S. Gordon, Jr., and W. Rosse. Studies on the metabolism of serum proteins and lipids in a patient with analbuminemia. Amer. J. Med. 1964, 37, 960.

27. Bennhold, H., and E. Kallee. Comparative studies on the half-life of $\mathrm{I}^{181}$-labeled albumins and nonradioactive human serum albumin in a case of analbuminemia. J. clin. Invest. 1959, 38, 863.

28. Bartter, F. C., J. L. Steinfeld, T. Waldmann, and C. A. Delea. Metabolism of infused serum albumin in the hypoproteinemia of gastrointestinal protein loss and in analbuminemia. Trans. Ass. Amer. Phycns 1961, 74, 180.

29. Brambell, F. W. R., W. A. Hemmings, C. L. Oakley, and R. R. Porter. The relative transmission of the fractions of papain hydrolyzed homologous $\gamma$-globulin from the uterine cavity to the foetal circulation in the rabbit. Proc. roy. Soc. B 1960 , 151, 478.

30. Gitlin, D., J. Kumate, J. Urrusti, and C. Morales. The selectivity of the human placenta in the transfer of plasma proteins from mother to fetus. J. clin. Invest. 1964, 43, 1938.

31. Brambell, F. W. R. The passive immunity of the young mammal. Biol. Rev. 1958, 33, 488.

32. Cohen, S., I. A. McGregor, and S. Carrington. Gamma globulin and acquired immunity to human malaria. Nature (Lond.) 1961, 192, 733.

33. Havens, W. P., Jr., J. Dickensheets, J. N. Bierly, and T. P. Eberhard. The half-life of $\mathrm{I}^{181}$ labeled normal human gamma globulin in patients with hepatic cirrhosis. J. Immunol. 1954, 73, 256.

34. Lippincott, S. W., S. Korman, C. Fong, E. Stickley, W. Wolins, and W. L. Hughes. Turnover of labeled normal gamma globulin in multiple myeloma. J. clin. Invest. 1960, 39, 565.

35. Fahey, J. L., and A. G. Robinson. Factors controlling serum $\boldsymbol{\gamma}$-globulin concentration. J. exp. Med. 1963, 118, 845.

36. Sell, S. Evidence for species' differences in the effect of serum $\gamma$-globulin concentration on $\gamma$-globulin catabolism. J. exp. Med. 1964, 120, 967.

37. Brambell, F. W. R., W. A. Hemmings, and I. G. Morris. A theoretical model of $\gamma$-globulin catabolism. Nature (Lond.) 1964, 203, 1352.

38. Solomon, A. Personal communication. 